Nig. J. Biotech. Vol. 37(2): 194-202 (Dec. 2020)

ISSN: 01891731

Available online at

http://www.ajol.info/index.php/njb/index

and www.biotechsocietynigeria.org

DOI: https://dx.doi.org/10.4314/njb.v37i2.19

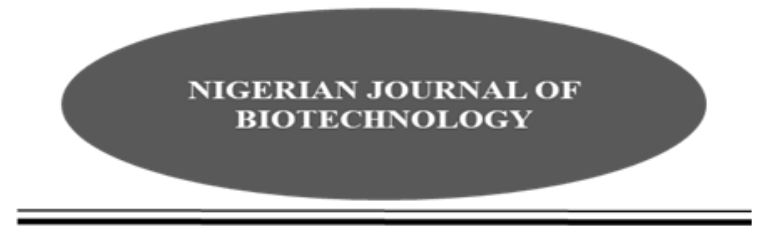

\title{
Effects of Gmelina arborea Powdered Parts on Mortality of Dinoderus porcellus in Yam Chips
}

\author{
John, W.C., ${ }^{1 *}$ Ishaya, M., ${ }^{1}$ Oladejo, A. $0 .,{ }^{1}$ Olori-Oke, $0 .,{ }^{1}$ Ihum, T. A. ${ }^{2}$ and \\ Ukanyirioha, C.J. ${ }^{1}$ \\ ${ }^{1}$ Federal College of Forestry, Jos, Plateau State, Nigeria. \\ ${ }^{2}$ Nigeria Stored Products Research Institute, Ilorin, Kwara State, Nigeria.
}

\begin{abstract}
The study aims at evaluating the efficacy of different doses of powdered stem and leaf parts of Gmelina arborea on Dinoderus porcellus infesting yam chips in Jos metropolis. The experiment was conducted at the Entomology Laboratory of the Federal College of Forestry, Jos. Samples of infested yam chips and Gmelina arborea were collected in Jos metropolis. Newly emerged adult Dinoderus porcellus were exposed to the yam chips which were mixed with different levels of Gmelina arborea parts powder $(0,5,10,15$ and 20 g). The setup was monitored for 120 hours and mortality recorded. The study was carried out in a randomized complete design with treatments replicated thrice. Data was analysed using analysis of variance at 1 and 5 percent confidence level and Duncan test was used to separate the means. The results obtained reveal significant differences at $p$ value $=0.05$ and 0.01 . The results reveal that in all the doses, an increase in the amount of the powder resulted in increased incidence of $D$. porcellus mortality. After 120 hours of exposure, $100 \%$ mortality was recorded from either 15 or $20 \mathrm{~g}$ stem bark + leaf powder treatment. From the results obtained, the use of $15 \mathrm{~g}$ stem bark+leaf powder of Gmelina arborea could be effective in yam chips preservation which could in turn strengthen food security.
\end{abstract}

Keywords: Yam chips; Dioscorea spp; Stem bark; Botanical; Leaf powder

*Corresponding Author Email: jwaltee@gmail.com Phone No. +2348064487369

Introduction

Yam (Dioscorea spp.) is a widely cultivated crop in Nigeria and it accounts for almost $75 \%$ of West Africa's yield (FAO, 1993). The world total production of yam is estimated at $95 \%$, most of which are cultivated across sub Saharan Africa (FAOstat, 2010). Among the yam species, D. rotundata (white yam), D. alata (water yam) and $D$. cayenesis (yellow or guinea yam) are the most produced and consumed in Nigeria (Amusa et al., 2003). Yam is a good source of carbohydrates, protein, vitamins and other essential minerals required by the body (Djeri et al., 2015). Yams are refined into several end products which are consumed in many parts of the tropics.

Industrially, yam tubers are converted into poultry and livestock feeds, starch and yam flour. A major characteristic of this vital crop is its efficiency in providing food security, and its flexibility in planting due to its storability over a long time (Ocitti, 2001).

Huge losses ( 30 to $85 \%$ of the entire production) are encountered by farmers during postharvest storage (Baco et al., 2004). Hence, it is important to preserve yam to avoid these losses and to prolong their shelf life for yearround consumption (Agyei-Amponsah et al., 
2014). To overcome the challenges of yam deteriorations and shortage of availability during the course of the year, consumers preserve yams traditionally by processing it into dried chips which further strengthen food security (Babajide et al., 2008).

Yam cultivation, marketing and consumption are adversely hampered by several pests both in the fields and in storages. The infestation of this important staple food by insect pests leads to spoilage of yam and reduction in yield (Okoroafor, 2009). Yam tubers are susceptible to several families of insect pests and diseases in farmland as well as in storage. Infestation of yams by beetles, fungi, viruses and nematodes are the most challenging.

To mitigate these effects, farmers adopt the use of synthetic pesticides in prevention and control of yam pests. However , these chemicals pose a major threat to consumer's health and environment (Kalia, 2011). This necessitates the search for safer control methods. Biological/botanical control methods are environmentally friendly and confer natural protections to the consumers. Several studies demonstrated that plants in Africa harbour some compounds with insecticidal potential. Based on this, the objective of the current study is to evaluate the mortality effect of stem bark and leaf powders of $G$. arborea on Dinoderus porcellus.

\section{Materials and Method \\ Samples Collection}

The infested yam chips were collected in a sterile polythene bag. Both the stem bark and leaves of Gmelina arborea were collected in clean polythene bags from the Federal College of Forestry, Jos, Nigeria, and submitted to a herbarium for identification. Twenty (20) fresh and healthy yam tubers (Dioscorea rotundata) were procured from Farin Gada market, Jos, Nigeria, and packaged in a sterile nylon bag. One thousand grams $(1000 \mathrm{~g})$ of infested yam chips was purchased from Fillin Ball market in Jos North Local government Area, plateau state.

Preparation of Gmelina arborea Stem Bark and Leaf Powder

The stem barks and leaves of Gmelina arborea were rinsed using clean water and dried at room temperature $\left(25^{\circ} \mathrm{C}\right)$ for 30 days, after which they were pulverized, using mortar and pestle, into powder. The powders were sieved to obtain fine particles using a 300 um pore -sized sieve (Loko et al., 2017). The powders were kept in polyethylene bags and stored for future use.

\section{Processing of Yam Chips}

Yam chips were made by slicing the collected yam tubers into pieces after peeling and washing under running water. The yam chips were boiled by heating in water at $50^{\circ} \mathrm{C}$ for $2 \mathrm{~h}$. The slices were removed and sun- dried for 21 days. The dried chips were sterilized at $60^{\circ} \mathrm{C}$ for $4 \mathrm{~h}$ and packaged in sterile polythene bags and kept in the laboratory at ambient temperature.

\section{Rearing of Dinoderus porcellus}

To obtain $D$. porcellus, infested yam chips were purchased from Filin Ball market and maintained on healthy yam chips in the laboratory following the method described by Onzo et al. (2015). This was carried out in cylindrical plastic boxes opened at one extremity. For aeration, holes were made at the end of the box and covered with Muslim cloth to prevent the insects from escaping. Dry yam chips $(500 \mathrm{~g})$ were infested in the plastic boxes with four hundred and fifty (450) adults of D. porcellus. The plastic boxes were kept on shelves in the laboratory at room temperature (Oni and Omoniyi, 2012). After two weeks of infestation, adult beetles were removed from the breeding boxes in order to obtain F1 generation that was used for all the experiments.

\section{Mortality Test}

Mortality investigation was conducted following the protocol described by Chebet et al. (2013) with little adjustment. Hundred grams of disinfected yam chips plus stem bark, leaf and stem bark + leaf powders of Gmelina arborea plant were mixed in a plastic box measuring 15 $\mathrm{cm}$ high and $20 \mathrm{~cm}$ width. Different dosages $(5,10,15$ and $20 \mathrm{~g})$ of the powdered plant parts were used. Adult insects (20), both male and female, were inoculated into the treated yam chips set up. Control was also set up (Insects + untreated yam chips). The boxes were sealed with a transparent muslin cloth to avoid escape of the insects. Dead insects were counted after every $24 \mathrm{hrs}$ for five days . Mortality rate was 
calculated using the equation of Asawalam et al. (2006)

Percent

Mortality= Number of D. porcellus introßark $d+\times$ leaf showed no significant difference

$(\mathrm{p} \leq 0.01)$ but all other treatments were significantly different at 120 hours (Table 5). Across the various doses and time of exposure of the different plant parts, analysis of variance indicated that there were significant differences $(p \leq 0.01)$ in mortality between the treated yam chips and the control (untreated yam chips).

The mortality of $D$. porcellus in the treated yam chips could be attributed to the phytochemical constituents of the botanicals used (Chebet et al., 2013). According to Iswarya et al. (2017) G. arborea is said to constitute compounds with pharmacological activities. Studies by De Bruyne et al. (1999) and Kaswala et al. (2012) showed that $\quad G$. arborea plant parts are strong antimicrobial agents. The tannin contained in $G$. arborea plant part powders possesses antiseptic, anti-inflammatory and antioxidant activities (Dolara et al., 2005). Extracts of medicinal botanicals have been implicated in respiratory disorder in insects leading to insect internal organs failure (Kedia et al., 2015).

Interestingly, though lower than the treated yam chips, the control showed some forms of mortality. This could be due to stress arising from handling or the insect health status. The results showed in this present study is in accordance with the investigation done by Estelle et al. (2018) whose results indicated that the combined $K$. senegalensis $B$. sapida and $B$. ferruginea leaf powders at all doses gave efficient ability in dealing with $D$. porcellus. Also, in another work by Angaye et al. (2017), the findings obtained are similar to this. Their study demonstrated larvicidal potential of Gmelina arborea after 90 days.

Table 1: Percent Mortality of Adult D. porcellus at 24 Hours

\begin{tabular}{llll}
\hline Treatment (g) & Mean $\mathbf{g}$ SD & & \\
\cline { 2 - 4 } & Leaf (\%) & Bark (\%) & $\begin{array}{l}\text { Leaf } \\
(\%)\end{array}$ \\
\hline $5 \mathrm{~g}$ & $3.33 \pm 2.89^{\mathrm{c}}$ & $3.33 \pm 2.89^{\mathrm{ab}}$ & $3.33 \pm 2.89^{\mathrm{b}}$ \\
$10 \mathrm{~g}$ & $6.67 \pm 2.89^{\mathrm{b}}$ & $3.67 \pm 2.89^{\mathrm{ab}}$ & $8.33 \pm 2.89^{\mathrm{ab}}$ \\
$15 \mathrm{~g}$ & $8.33 \pm 2.89^{\mathrm{b}}$ & $6.67 \pm 2.89^{\mathrm{a}}$ & $10.00 \pm 5.00^{\mathrm{ab}}$ \\
$20 \mathrm{~g}$ & $11.67 \pm 2.89^{\mathrm{a}}$ & $5.00 \pm 5.00^{\mathrm{ab}}$ & $15.00 \pm 5.00^{\mathrm{a}}$ \\
$0 \mathrm{~g}$ & $1.40 \pm 2.00^{\mathrm{d}}$ & $0.80 \pm 0.00^{\mathrm{b}}$ & $1.10 \pm 0.00^{\mathrm{c}}$ \\
\hline ANOVA & 9.125 & 2.083 & 7.688
\end{tabular}




\section{P-value}

$0.002 * *$

0.158

$0.004 * *$

Values are means of triplicate readings. Mean values were separated using Duncan multiple range tests. Mean values with different superscripts in the same column are significantly different.

NA: Not applicable.

* $=$ significant difference exists at $p \leq 0.05$

** $=$ significant difference exists at $p \leq 0.01$

Table 2: Percent Mortality of Adult D. porcellus at 48 Hours

\begin{tabular}{llll}
\hline \multirow{2}{*}{ Treatment (g) } & Mean \pm SD & & \\
\cline { 2 - 4 } & Leaf (\%) & Bark (\%) & $\begin{array}{l}\text { Leaf } \\
(\%)\end{array}$ \\
\hline $5 \mathrm{~g}$ & $15.00 \pm 5.00^{\mathrm{b}}$ & $16.67 \pm 5.77^{\mathrm{a}}$ & $16.67 \pm 5.77^{\mathrm{d}}$ \\
$10 \mathrm{~g}$ & $23.33 \pm 2.89^{\mathrm{a}}$ & $15.00 \pm 5.00^{\mathrm{a}}$ & $26.67 \pm 2.89^{\mathrm{c}}$ \\
$15 \mathrm{~g}$ & $26.87 \pm 2.89^{\mathrm{a}}$ & $18.33 \pm 2.89^{\mathrm{a}}$ & $35.00 \pm 5.00^{\mathrm{b}}$ \\
$20 \mathrm{~g}$ & $28.33 \pm 2.89^{\mathrm{a}}$ & $16.67 \pm 2.89^{\mathrm{a}}$ & $43.33 \pm 2.89^{\mathrm{a}}$ \\
$0 \mathrm{~g}$ & $6.11 \pm 0.00^{\mathrm{c}}$ & $2.33 \pm 0.00^{\mathrm{b}}$ & $3.78 \pm 0.00^{\mathrm{e}}$ \\
\hline ANOVA & 40.583 & 11.389 & 56.556 \\
P-value & $<0.001^{* *}$ & $0.001^{* *}$ & $<0.001^{* *}$ \\
\hline
\end{tabular}

Values are means of triplicate readings. Mean values were separated using Duncan multiple range tests. Mean values with different superscripts in the same column are significantly different.

NA: Not applicable.

* $=$ significant difference exists at $p \leq 0.05$

** $=$ significant difference exists at $p \leq 0.01$

Table 3: Percent Mortality of Adult D. porcellus at 72 Hours

\begin{tabular}{|c|c|c|c|}
\hline \multirow[b]{2}{*}{ Treatment (g) } & \multicolumn{3}{|l|}{ Mean \pm SD } \\
\hline & Leaf (\%) & Bark (\%) & $\begin{array}{l}\text { Leaf+Bark } \\
(\%)\end{array}$ \\
\hline $5 \mathrm{~g}$ & $31.67 \pm 2.89^{c}$ & $35.00 \pm 5.00^{\mathrm{ab}}$ & $45.00 \pm 5.00^{d}$ \\
\hline $10 \mathrm{~g}$ & $43.33 \pm 2.89^{b}$ & $33.33 \pm 2.89^{b}$ & $56.67 \pm 2.87^{c}$ \\
\hline $15 \mathrm{~g}$ & $48.33 \pm 2.89^{a b}$ & $41.67 \pm 2.89^{a}$ & $66.67 \pm 2.87^{b}$ \\
\hline $20 \mathrm{~g}$ & $53.33 \pm 7.64^{a}$ & $41.67 \pm 5.77^{a}$ & $73.33 \pm 2.87^{a}$ \\
\hline $0 \mathrm{~g}$ & $7.45 \pm 0.00^{d}$ & $5.03 \pm 0.00^{c}$ & $4.22 \pm 0.00^{\mathrm{e}}$ \\
\hline ANOVA & 81.850 & 60.389 & 2536.333 \\
\hline P-value & $<0.001^{* *}$ & $<0.001 * *$ & $<0.001^{* *}$ \\
\hline
\end{tabular}

Values are means of triplicate readings. Mean values were separated using Duncan multiple range tests. Mean values with different superscripts in the same column are significantly different.

NA: Not applicable.

* $=$ significant difference exists at $p \leq 0.05$

$* *=$ significant difference exists at $p \leq 0.01$

Table 4: Percent Mortality of Adult D. porcellus at 96 Hours

\begin{tabular}{llll}
\hline \multirow{2}{*}{ Treatment (g) } & Mean \pm SD & \multicolumn{2}{l}{} \\
\cline { 2 - 4 } & Leaf (\%) & Bark (\%) & $\begin{array}{l}\text { Leaf } \\
(\%)\end{array}$ \\
\hline $5 \mathrm{~g}$ & $51.67 \pm 2.89^{\mathrm{c}}$ & $61.67 \pm 5.77^{\mathrm{bc}}$ & $71.67 \pm 2.89^{\mathrm{d}}$ \\
$10 \mathrm{~g}$ & $65.00 \pm 5.00^{\mathrm{b}}$ & $60.00 \pm 5.00^{\mathrm{c}}$ & $81.67 \pm 2.89^{\mathrm{c}}$ \\
$15 \mathrm{~g}$ & $75.00 \pm 5.00^{\mathrm{a}}$ & $68.33 \pm 2.89^{\mathrm{ab}}$ & $91.67 \pm 2.89^{\mathrm{b}}$ \\
$20 \mathrm{~g}$ & $80.00 \pm 8.66^{\mathrm{a}}$ & $70.00 \pm 5.00^{\mathrm{a}}$ & $96.67 \pm 2.89^{\mathrm{a}}$ \\
$0 \mathrm{~g}$ & $9.420 \pm 0.00^{\mathrm{d}}$ & $11.13 \pm 0.00^{\mathrm{d}}$ & $8.34 \pm 0.00^{\mathrm{e}}$ \\
\hline
\end{tabular}




\begin{tabular}{llll}
\hline ANOVA & 116.969 & 141.227 & 698.125 \\
P-value & $<0.001 * *$ & $<0.001^{* *}$ & $<0.001^{* *}$ \\
\hline Values are & &
\end{tabular}

Values are means of triplicate readings. Mean values were separated using Duncan multiple range tests. Mean values with different superscripts in the same column are significantly different.

NA: Not applicable.

* = significant difference exists at $p \leq 0.05$

** $=$ significant difference exists at $p \leq 0.01$

Table 5: Percent Mortality of Adult D. porcellus at 120 Hours

\begin{tabular}{llll}
\hline \multirow{2}{*}{ Treatment (g) } & Mean \pm SD & & \\
\cline { 2 - 4 } & Leaf (\%) & Bark (\%) & Leaf +Bark (\%) \\
\hline $5 \mathrm{~g}$ & $80.00 \pm 5.00^{\mathrm{c}}$ & $90.00 \pm 5.00^{\mathrm{b}}$ & $91.67 \pm 5.77^{\mathrm{b}}$ \\
$10 \mathrm{~g}$ & $90.00 \pm 5.00^{\mathrm{b}}$ & $93.33 \pm 2.89^{\mathrm{ab}}$ & $96.67 \pm 2.89^{\mathrm{ab}}$ \\
$15 \mathrm{~g}$ & $96.67 \pm 2.89^{\mathrm{a}}$ & $95.00 \pm 5.00^{\mathrm{ab}}$ & $100.00 \pm 0.00^{\mathrm{a}}$ \\
$20 \mathrm{~g}$ & $98.33 \pm 2.89^{\mathrm{a}}$ & $98.33 \pm 2.89^{\mathrm{a}}$ & $100.00 \pm 0.00^{\mathrm{a}}$ \\
$0 \mathrm{~g}$ & $12.61 \pm 0.00^{\mathrm{d}}$ & $12.52 \pm 0.00^{\mathrm{c}}$ & $9.82 \pm 0.00^{\mathrm{c}}$ \\
\hline ANOVA & 386.375 & 401.063 & 682.800 \\
P-value & $<0.001^{* *}$ & $<0.001^{* *}$ & $<0.001^{* *}$ \\
\hline
\end{tabular}

Values are means of triplicate readings. Mean values were separated using Duncan multiple range tests. Mean values with different superscripts in the same column are significantly different.

NA: Not applicable.

* = significant difference exists at $p \leq 0.05$

$* *=$ significant difference exists at $p \leq 0.01$

The activities of the various doses of Gmelina arborea powdered parts against $D$ porcellus showed significant differences across the various time intervals except at 24 and 120 hours. The results depicted in Table 8 illustrated that the use of $20 \mathrm{~g}$ Stem bark + leaf powder exhibited the highest insect mortality value of $43.33 \pm 2.89 \%$ when compared with other parts at the same time (48 hours). This trend continued as the time of exposure was extended.

Analysis of variance indicated significant difference $(p \leq 0.01)$ at 96 hours. Twenty grams of stem bark + leaf showed the highest mortality value of $96.67 \pm 2.89 \%$ while the lowest mortality value of $51.67 \pm 2.89 \%$ was observed using $5 \mathrm{~g}$ leaf powder at the same time (96 hours) (Table 9). Interestingly, at 120 hours, all the doses of Gmelina arborea powdered part $(5,10,15$ and 20) indicated no significant difference ( $p \leq 0.01$ ), however, $100 \%$ mortality was recorded using either 15 or $20 \mathrm{~g}$ stem bark + leaf powder (Table 10).

In general, the comparative analysis revealed that increasing the time of exposure of $D$. porcellus to Gmelina arborea powdered part dose increased the rate of $D$. porcellus mortality. This is consistent with the study of Oladejo et al. (2020) which demonstrated that increase in concentrations of the treatments and extended time led to increased mortality rate of $\quad$ S. zeamais. The efficacy of the different parts of Gmelina arborea part powders on insects varied. Aktar, (2004) suggested that it could be due to species susceptibility and chemical composition. In the current research, mortality of adults $D$. porcellus varied with the dosage of the plant parts. The results of this work revealed that in all the doses, an increase in the amount of the powder resulted in lower incidence of $D$ porcellus infestation.

Botanicals in several parts of the world especially in developing countries have been consumed due to their health benefits. Report by WHO revealed that developing countries like India, depend solely on medicinal plants and compounds from botanicals for the treatment of different illnesses (Sakthivel et al., 2017).

Table 6: Comparative Percent Mortality Effect of G. arborea Powders at 24 Hours

\begin{tabular}{llll}
\hline Treatment (g) & Mean \pm SD & ANOVA & P-value \\
\hline
\end{tabular}




\begin{tabular}{llllll}
\hline & Leaf (\%) & Bark (\%) & $\begin{array}{l}\text { Leaf } \\
(\%)\end{array}$ & +Bark & \\
\hline $5 \mathrm{~g}$ & $3.33 \pm 2.89$ & $3.33 \pm 2.89$ & $3.33 \pm 2.89$ & 0.000 & 1.000 \\
$10 \mathrm{~g}$ & $6.67 \pm 2.89$ & $1.67 \pm 2.89$ & $8.33 \pm 2.89$ & 4.333 & 0.068 \\
$15 \mathrm{~g}$ & $8.33 \pm 2.89$ & $6.67 \pm 2.89$ & $10.00 \pm 5.00$ & 0.600 & 0.579 \\
$20 \mathrm{~g}$ & $11.67 \pm 2.89$ & $5.00 \pm 5.00$ & $15.00 \pm 5.00$ & 4.000 & 0.079 \\
$0 \mathrm{~g}$ & $1.01 \pm 0.66$ & $1.40 \pm 1.01$ & $1.07 \pm 2.60$ & NA & NA \\
\hline
\end{tabular}

Values are means of triplicate readings. Mean values were separated using Duncan multiple range tests. Mean values with different superscripts in the same row are significantly different.

NA: Not applicable.

* $=$ significant difference exists at $p \leq 0.05$

$* *=$ significant difference exists at $p \leq 0.01$

Table 7: Comparative Percent Mortality Effect of G. arborea Powders at 48 Hours

\begin{tabular}{|c|c|c|c|c|c|}
\hline \multirow[b]{2}{*}{ Treatment (g) } & \multicolumn{3}{|l|}{ Mean \pm SD } & \multirow[b]{2}{*}{ ANOVA } & \multirow[b]{2}{*}{ p-value } \\
\hline & Leaf (\%) & Bark (\%) & $\begin{array}{l}\text { Leaf } \\
(\%)\end{array}$ & & \\
\hline $5 \mathrm{~g}$ & $15.00 \pm 5.00$ & $16.67 \pm 5.77$ & $16.67 \pm 5.77$ & 0.091 & 0.914 \\
\hline $10 \mathrm{~g}$ & $23.33 \pm 2.89^{a}$ & $15.00 \pm 5.00^{b}$ & $26.67 \pm 2.89^{a}$ & 7.800 & $0.021 *$ \\
\hline $15 \mathrm{~g}$ & $26.87 \pm 2.89^{b}$ & $18.33 \pm 2.89^{c}$ & $35.00 \pm 5.00^{a}$ & 15.000 & $0.005 * *$ \\
\hline $20 \mathrm{~g}$ & $28.33 \pm 2.89^{b}$ & $16.67 \pm 2.89^{c}$ & $43.33 \pm 2.89^{a}$ & 64.333 & $<0.001 * *$ \\
\hline $0 \mathrm{~g}$ & $2.90 \pm 0.50$ & $2.20 \pm 9.01$ & $2.00 \pm 0.00$ & NA & NA \\
\hline
\end{tabular}

Values are means of triplicate readings. Mean values were separated using Duncan multiple range tests. Mean values with different superscripts in the same row are significantly different.

NA: Not applicable.

$*$ significant difference exists at $p \leq 0.05$

** $=$ significant difference exists at $p \leq 0.01$

Table 8: Comparative Percent Mortality Effect of G. arborea Powders at 72 Hours

\begin{tabular}{|c|c|c|c|c|c|}
\hline \multirow[b]{2}{*}{ Treatment (g) } & \multicolumn{3}{|l|}{ Mean \pm SD } & \multirow[b]{2}{*}{ ANOVA } & \multirow[b]{2}{*}{ p-value } \\
\hline & Leaf (\%) & Bark (\%) & $\begin{array}{l}\text { Leaf+Bark } \\
(\%)\end{array}$ & & \\
\hline $5 \mathrm{~g}$ & $31.67 \pm 2.89^{b}$ & $35.00 \pm 5.00^{b}$ & $45.00 \pm 5.00^{a}$ & 7.429 & 0.024 \\
\hline $10 \mathrm{~g}$ & $43.33 \pm 2.89^{b}$ & $33.33 \pm 2.89^{c}$ & $56.67 \pm 2.87^{a}$ & 49.333 & $<0.001 * *$ \\
\hline $15 \mathrm{~g}$ & $48.33 \pm 2.89^{b}$ & $41.67 \pm 2.89^{c}$ & $66.67 \pm 2.87^{a}$ & 60.333 & $<0.001 * *$ \\
\hline $20 \mathrm{~g}$ & $53.33 \pm 7.64^{b}$ & $41.67 \pm 5.77^{c}$ & $73.33 \pm 2.87^{a}$ & 23.083 & $0.002 * *$ \\
\hline $0 \mathrm{~g}$ & $5.33 \pm 0.22$ & $7.61 \pm 5.04$ & $5.01 \pm 0.08$ & NA & NA \\
\hline
\end{tabular}

Values are means of triplicate readings. Mean values were separated using Duncan multiple range tests. Mean values with different superscripts in the same row are significantly different.

NA: Not applicable.

$*$ significant difference exists at $p \leq 0.05$

$* *$ significant difference exists at $p \leq 0.01$

Table 9: Comparative Percent Mortality Effect of G. arborea Powders at 96 Hours

\begin{tabular}{|c|c|c|c|c|c|c|}
\hline \multirow[b]{2}{*}{ Treatment (g) } & \multicolumn{4}{|l|}{ Mean \pm SD } & \multirow[b]{2}{*}{ ANOVA } & \multirow[b]{2}{*}{ p-value } \\
\hline & Leaf (\%) & Bark (\%) & $\begin{array}{l}\text { Leaf } \\
(\%)\end{array}$ & +Bark & & \\
\hline $5 \mathrm{~g}$ & $51.67 \pm 2.89^{c}$ & $61.67 \pm 5.77^{b}$ & 71.67 & $2.89^{a}$ & 18.000 & $0.003 * *$ \\
\hline $10 \mathrm{q}$ & $65.00 \pm 5.00^{b}$ & $60.00 \pm 5.00^{b}$ & 81.67 & $2.89^{a}$ & 19.857 & $0.002 * *$ \\
\hline $15 \mathrm{~g}$ & $75.00 \pm 5.00^{b}$ & $68.33 \pm 2.89^{b}$ & 91.67 & $2.89^{a}$ & 31.200 & $0.001^{* *}$ \\
\hline
\end{tabular}


John et al. /Nig. J. Biotech. Vol. 37 Num. 2: 194-202 (Dec 2020)

\begin{tabular}{llllll}
\hline $20 \mathrm{~g}$ & $80.00 \pm 8.66^{\mathrm{b}}$ & $70.00 \pm 5.00^{\mathrm{b}}$ & $96.67 \pm 2.89^{\mathrm{a}}$ & 15.077 & $0.005^{* *}$ \\
$0 \mathrm{~g}$ & $7.19 \pm 0.55$ & $8.37 \pm 3.02$ & $6.08 \pm 2.04$ & $\mathrm{NA}$ & $\mathrm{NA}$ \\
\hline
\end{tabular}

Values are means of triplicate readings. Mean values were separated using Duncan multiple range tests. Mean values with different superscripts in the same row are significantly different.

NA: Not applicable.

* $=$ significant difference exists at $p \leq 0.05$

** $=$ significant difference exists at $p \leq 0.01$

Table 10: Comparative Percent Mortality Effect of G. arborea Powders at 120 Hours

\begin{tabular}{llllll}
\hline \multirow{2}{*}{ Treatment (g) } & Mean \pm SD & & \multirow{2}{*}{ ANOVA } & \multirow{2}{*}{ p-value } \\
\cline { 2 - 5 } & Leaf (\%) & Bark (\%) & Leaf +Bark (\%) & & \\
\hline $5 \mathrm{~g}$ & $80.00 \pm 5.00$ & $90.00 \pm 5.00$ & $91.67 \pm 5.77$ & 4.300 & 0.069 \\
$10 \mathrm{~g}$ & $90.00 \pm 5.00$ & $93.33 \pm 2.89$ & $96.67 \pm 2.89$ & 2.400 & 0.171 \\
$15 \mathrm{~g}$ & $96.67 \pm 2.89$ & $95.00 \pm 5.00$ & $100.00 \pm 0.00$ & 1.750 & 0.252 \\
$20 \mathrm{~g}$ & $98.33 \pm 2.89$ & $98.33 \pm 2.89$ & $100.00 \pm 0.00$ & 0.500 & 0.630 \\
$0 \mathrm{~g}$ & $9.20 \pm 3.30$ & $10.17 \pm 0.60$ & $9.93 \pm 2.09$ & NA & NA \\
\hline
\end{tabular}

Values are means of triplicate readings. Mean values were separated using Duncan multiple range tests. Mean values with different superscripts in the same row are significantly different.

NA: Not applicable.

${ }^{*}=$ significant difference exists at $p \leq 0.05$

$* *=$ significant difference exists at $p \leq 0.01$

\section{Conclusion}

Post-harvest losses caused by Dinoderus porcellus is a major challenge facing farmers in Nigeria, hence the need for research of this kind. From the results obtained, the botanical powders showed more efficacy against Dinoderus porcellus as the dose level and time of exposure are increased. Stem bark + leaf powder exhibited $100 \%$ mortality at 120 hours using 15 $\mathrm{g}$ powder. The readily availability and environment friendliness of Gmelina arborea makes it a good yam chips preservative which will lead to reduced post-harvest losses. Further work is encouraged to determine the effectiveness of this botanical against other pests of yam under.

\section{References}

Agyei-Amponsah, J., Owureku-Asare, Agbemavor, W.S.K., Armah, J., Okyere, A., Baidoo, E., Dowuona, S. and Tortoe, C. (2014). Quality Characteristics of Pre-treated Yam Chips Produced from Irradiated Yams. Brit. J. Appl. Sci. \& Tech. 4(36): 5045-5057.

Aktar, Y, Isman, M.B. (2004) Comparative growth inhibitory and antifeedant effects of plant extracts and pure allelochemicals on four phytophagous insect species. J. Appl. Entom. 128(1): 32-38.

Amusa, N. A., Adegbite, A. A., Muhammed, S. and Baiyewu, R. A. (2003). Yam diseases and its management in Nigeria. Afri. J. Biotech. 2 (12):497-502.

Angaye, T.C.N., Oyinke, G.N., Angaye, W.W.T., Igbeinkutu, V.D. (2017). The Comparative Phytochemical and Bio-larvicidal Efficacy of Leaf Extracts of Gmelina arborea against Mosquito Larvae. Int. J. Innov. Healthcare Res. 5(1):1-6.

Asawalam, E.F., Emosairue, S.O., Hassanali, A. (2006). Bioactivity of Xylopia aetiopica (Dunal) a rich essential oil constituent on maize weevil Sitophilus zeamais Motch (Coleoptera: Curculionidae). Electron. J. Env. Agric. Food Chem. 5:1195-1204.

Babajide, J.M., Atanda, O. O., Ibrahim, T. A., Majolagbe, H. O. and Akinbayode, S. A. (2008). Quantitative effect of 'abafe' (Piliostigma thionnigii) and 'agehu' (Khaya ivorensis) leaves on the microbial load of dry-yam 'gbodo'. Afri. J. Microb. Res. 2: 292-298. 
Baco, M. N., Tostain, S., Mongbo, R. L., Dainou, O. and Agbangla, C. (2004). Gestion dynamique de la diversite vari' etale des 'ignames cultivees (Dioscorea cayenensis - D. rotundata) dans la commune de Sinende au nord B' enin. Plant Genet. Resour. Newsle. 139: 18-24.

Chebet, F., Deng, A.L., Ogendo, J.O., Kamau, A.W., Bett, P.K. (2013). Bioactivity of selected plant powders against Prostephanus truncates (Coleoptera: Bostrichidae) in stored maize grains. Plant Prot. Sci. 49(1):34-43.

Chothani, D.L. and Patel, N.M. (2018). Phytochemical screening and quantification of phytoconstituents in Gmelina arborea fruits extract. J. Med. Plants Stud. 6(4): 31-35.

De Bruyne, T., Pieters, L., Deelstra, H. and Vlietinck, A. (1999). Condensed vegetables tannins: biodiversity in structure and biological activities. Biochem. Syst. Ecol. 27: 445-59.

Djeri, B., Tchobo, P.F., Adjrah, Y., Karou, D.S., Ameyapoh, Y., Soumanou, M.M., Souza, C. (2015). Nutritional potential of yam chips (Dioscorea cayenensis-Dioscorea rotundata Poir) obtained using two methods of production in Togo. Afri. J. Food Sci. 9(5):278-284.

Dolara, P., Luceri, C., De Filippo, C., Femia, A.P., Giovannelli, L., Carderni, G., Cecchini, C., Silvi, S., Orpianesi, C. and Cresci, A. (2005). Red wine polyphenols influence on carcinogenesis, intestinal microflora, oxidative damage and gene expression profiles of colonic mucosa in F344 rats. Mutat. Res. 591: 237-46.

Estelle, L.Y.L., Gnaho, A.C., Toffa J., Orobiyi A., Dansi, A. and Tamò M. (2012). Management of Dinoderus porcellus L. (Coleoptera: Bostrichidae) infesting yam chips using varietal resistance and botanical powders of three medicinal plants. Afri. J. Agric. Res. 13(40):2118-2133.

FAO (1993) FAO yearbook, FAO Rome Italy: 95.

FAO, FAOSTAT Database. (2010). Food and Agriculture Organization, Roma, Italy. http://www.fao.org/.
Iswarya S., Sridevi M., Mayavel A. (2017). Comparative Study on Phytochemical and Antioxidant Properties of Gmelina arborea Roxb. From four Different Geographical Regions. Int. J. Pharm. Clin. Res. 9(4): 275-280.

Kalia, Grade 8 (2011). Plant Extracts as Natural Insecticides. Part of the Young Naturalist Awards Curriculum Collection. Young Naturalist Awards Collect. New York TNA Winner.

Kaswale, R., Patel, V., Chakraboty, M., Kamat, J. V. (2012). Phytochemical and Phamarcological Profile of Gmelina arborea; An Overview. Int. J. Pharm. 3(2): 61 - 64.

Kedia, A., Prakash, B., Mishra, P.K., Singh, P., Dubey, N.K. (2015). Botanicals as ecofriendly biorational alternatives of synthetic pesticides against Callosobruchus spp (Coleoptera: Bruchidae)-a review. J. Food Sci. \& Tech. 52(3):1239-1257.

Loko, Y.I., Gnaho, A.C., Orobiyi, A., Agre, P., Dangi, A.(2017). Resistance of dried chips yam Dioscorea cayenensis- $D$. rotundata omplex) landraces to Dinoderus porceliuslesine (coleopteran Bostrictide). Cog. food \& Agric. 3(1): 141180.

Ocitti, P. and Obwoya, C.N. (2001). Yams. 229232 in Mukiibi J.K. (Ed.) Agriculture in Uganda Vol II Crops. Fountain Publishers Kampala Uganda/ CTA/ NARO.

Okoroafor E (2009). Bio-efficacy of some Botanical for the control of yam beetle, Heteroligus meles Billberger (Coleoptera: Dynastidae) in Benue State, Nigeria. PhD Dissertation. Ahmadu Bello University, Zaria. Pp. 130.

Oladejo, A.O., Sikiru, GK., Popoola, A.S., Adedire, O. and Olori-oke, O. (2020). Insecticidal effects of Gmelina arborea stem bark and leaf powder on Sitophilus zeamais (Maize weevil) on stored maize grains. J. Afri. Sustain. develop. 18(2):225-234.

Oni, O. A. (2012). A studies on temperature influence on oviposition and Development of immature stages of the yam beetle 
DinoderusPorcelluslenseColeopeterabostrichidea on dried yam species. J. Agric. sci. 9(4)67-71.

Onzo, A., Biaou, J.T., Loko, L.T, Tamo, M., Dansi, A. (2015). Vulnerability des cossettes issues de quelques cultivars digname a $\mathrm{I}^{\prime}$ attaque de binoderuspocelluslesne (coleopteran bostrichidae) en conditions de laboratoire. Int. J. Biol. \& Chem. Sci. 6(4)564-571.

Sakthive, S., Sheik A. S. and Amanullah, S. (2017). Analysis the Extract of Barks in Gmelina Arborea in Different Dilution and Phytochemical Examination in Ethanol Extraction. Int. J. Pharm. Sci. Invent. 6 (9):37-43. 